\title{
PENGARUH LIKUIDITAS, SOLVABILITAS DAN \\ PERPUTARAN AKTIVA TERHADAP PROFITABILITAS PADA PERUSAHAAN LEADER SUPERMARKET DI DILI TIMOR-LESTE
}

\author{
Marcelina Freitas Ximenes
}

\author{
Fakultas Ekonomi dan Bisnis Universitas Udayana, Bali, Indonesia \\ Email : MFXmarcal@yahoo.com
}

\begin{abstract}
ABSTRAK
Tujuan utama perusahaan adalah untuk memaksimalkan kemakmuran bagi pemegang sahamnya. Salah satu cara untuk mencapai tujuan tersebut adalah dengan meningkatkan profitabilitas perusahaan. segala sumber daya perusahaan harus dimanfaatkan semaksimal mungkin agar dapat memperoleh profitabilitas. Likuiditas, solvabilitas dan perputaran aktiva merupakan bagian dari sumber daya yang dapat berdampak langsung pada profit perusahaan. Pemeliaran efisensi perusahaan untuk menghasilkan keuntungan yang diharapkan, investor dapat melihat dari sisi pengaruh rasiorasio yang dimiliki perusahaan terhadap profitabilitas. Semakin efisien rasio-rasio yang digunakan perusahaan, maka semakin tinggi profitabilitas yang dapat dicapi. Penelitian ini bertujuan untuk mengetahui pengaruh kebijakan likuiditas, solvabilitas dan perputaran aktiva terhadap profitabilitas pada perusahaan leader supermarket di Dili Timor-Leste pada periode 2009-2013. Teknik analisa data yang digunakan adalah teknik analisis regresi linier berganda. Profitabilitas menunjukkan keunggulan perusahaan dalam persaingan bisnis, yang mana tingkat profitabilitas semakin tinggi maka kinerja perusahaan semakin baik. Kebijakan modal kerja sangat diperlukan untuk mencapai keunggulan persaingan tersebut sehingga para calon investor yang ingin berinvestasi pada perusahaan leader super market di Dili Timor-Leste hendaknya memperhatikan perputaran aktiva terutama yang memberikan profitabilitas tinggi.

Kata kunci : Likuiditas, Solvabilitas, Perputaran Aktiva dan Profitabilitas.
\end{abstract}

\begin{abstract}
The main objective of the company is to maximize wealth for shareholders. One way to achieve this goal is to improve the profitability of the company. All the company's resources should be utilized as much as possible in order to obtain profitability. Liquidity, solvency and asset turnover are part of the resource which can have a durect impact on corporate profits. In improving the efficiency of the company to generate the expected profit, Investor can see from the side effects of ratios of the company on profitability. The more efficient ratios used by the company, the higher profitability can be achieved. This study aimed to determine the effect of the policy of liquidity, solvability and asset turnover on profitability in the campany Supermarket Leader in Dili Timor-Leste in 2009 - 2013 period. The data analysis technique used was the technique of multiple linear regression analysis. Profitability of the company demonstrates excellences in business competition where the is higher the level of profitability of the company's performance the better. Working capital policcy is badly needed to achieve a competitive advantage so that the potential investor who want to invest in the company Supermarket Leader in Timor-Leste should consider variable of working capital those providing high profitability.
\end{abstract}

Keywords: Liquidity, Solvability, Asset Turnover and profitability. 


\section{PENDAHULUAN}

\section{Latar Belakang Masalah}

Pada dasarnya tujuan perusahaan adalah untuk memperoleh profit atau keuntungan yang maksimal danberkelanjutan, didasari oleh pentingnnya peranan dunia usaha dalam mewujudkan kesejaterahaan masyarakat maka setiap badan usaha swasta harus memiliki posisi keuangan dan kinerja yang baik yang akan menjadi dasar bagi perusahaan untuk mempertahankan dan menjamin kelangsungan usahanya dimasa yang akan datang. Usaha untuk memperjuangkan dan mempertahankan serta mengembangkkan perusahaan dalam pengelolaanya harus dilakukan secara profisional dengan memperhatikkan hal-hal yang mendukung kelansungan hidup perusahaan. Adapun beberapa hal penting yang perlu diperhatikan dalam mencapai profitabilitas adalah rasio Likuiditas, rasio Solvabilitas dan rasio Aktivitas terhadap profitabilitas yang dicapai oleh perusahaan.

Menurut Munawir (2007:240), menjelaskan bahwa "profitabilitas adalah rasio yang digunakan untuk menilai kemampuan perusahaan untuk memperoleh keuntungan.” Berdasarkan pendapat tersebut maka dapat dikatakan bahwa rasio profitabilitas merupakan rasio yang digunakan untuk mengukur kemampuan perusahaan untuk memperoleh keuntungan yang memcerminkan baik atau buruknya manajemen dalam mengelola perusahaan dalam bentuk presentase. Jadi dalam penelitian ini profitabilitas akan diukur dengan menggunakan returnonassets (ROA). ROA merupakan rasio keuangan yang menunjukkan kemampuan perusahaan untuk menghasilkan laba dari aktiva yang dipergunakan. 
Analisis ROA mengukur kemampuan perusahaan menghasilkan laba pada masa lalu, yang nantinya dapat diproyeksikan kemasa depan untuk melihat kemampuan perusahaan menghasilkan laba di masa mendatang.

Bagi supermarket profitabilitas adalah penting sebagai ukuran supermarket itu telah dapat bekerja dengan efisien atau tidak. Efisien baru diketahhui dengan membandingkann antara laba yang diperoleh dalam suatu periode dengan jumlah aktiva artau modal supermarket. Supermarket memerlukan pengelolaan yang baik tentang modal kerjanya yang meliputi kas, piutang dan persediaan serta perlu mengetahui profitabilitasnya. Agar supermarket dapat mencapai profitabilitas seperti yang dikehendaki, maka sebaiknya pihak supermarket dapat mengelola aset yang dimilikinya dengan baik.

Kemampuan leader supermarket dalam memenuhi kewajiban finansialnya yang harus segera terpenuhi serta untuk memperoleh gambaran tentang seberapa efektif supermarket mengelola asetnya perlu dilakukan suatu analisis terhadap laporan keuanggan supermarket yang meliputi rasio keuangan. Rasio tersebut dapat memberikan indikasi apakah suatu supermarket memiliki kas yang cukup untuk memenuhi kewajiban finansialnya, dan perencanaan pengeluaran investasi yang baik dan struktur modal yang sehat sehingga memaksimumkan tujuan yaitu kemakmuran yang dicapai oleh pemilik supermarket.

Tiga komponen yaitu likuiditas, solvabilitas dan berputaran aktiva, ketiga komponen tersebut dapat dikelola dengan cara yang berbeda untuk untuk memaksimalkan profitabilitas atau untuk meningkatkan pertumbuhan perusahaan (Lazaridis daan Tryfonidis, 2006). 


\section{Tujuan Penelitian}

Berdasarkan rumusan masalah, maka metode penelitian ini adalah sebagai berikut:

1) Untuk mengetahui signifikansi pengaruh likuiditas terhadap profitabilitas pada Leader Supermarket di dili Timor-Leste.

2) Untuk mengetahui signifikansi pengaruh solvabilitas terhadap profitabilitas pada Leader Supermarket di dili Timor-Leste.

3) Untuk mengetahui signifikansi pengaruh perputaran aktiva terhadap profitabilitas pada Leader Supermarket di dili Timor-Leste.

4) Untuk mengetahui signifikansi pengaruh likuiditas, solvabilitas dan perputaran aktiva secara simultan terhadap profitabilitas pada Leader Supermarket di Dili Timor-Leste pada tahun 2009-2013.

\section{Manfaat Hasil Penelitian}

Berdasarkan rumusan masalah dan tujuan penelitian, manfaat dari penelitian ini dibedakan sebagai berikut:

\section{Manfaat Teoritis}

Penelitian ini harapkan dapat memberikan kontribusi dalam bentuk bukti empiris terhadap teori manajemen keuangan mengenai pengaruh likuiditas, solvabilitas dan perputaran aktiva terhadap profitabilitas.

\section{Manfaat Praktis}

Penelitian ini diharapkan dapat menjadi referensi bagi pihak manajemen perusahaan leader supermarket untuk meningkatkan operasional perusahaan dalam mengambil kebijakan untuk memasimalkan profitabilitas perusahaan 


\section{KAJIAN PUSTAKA}

Profitabilitas menurut Wiagustini (2010) adalah kemampuan perusahaan untuk menghasilkan laba selama periode tertentu. Brigham and Dave (2010) mengemukakan bahwa profitabilitas adalah hasil bersih dari serangkaian kebijakan dan keputusan.

Profitabilitas adalah kemampuan perusahaan memperoleh laba dalam hubungannya dengan penjualan, total aktiva maupun modal sendiri (Sartono 2010:122). Bagi perusahaan masalah profitabilitas sangat penting. Bagi pimpinan perusahaan, profitabilitas digunakan sebagai tolak ukur berhasil atau tidaknya perusahaan yang dipimpinnya. Sedangkan bagi karyawan perusahaan semakin tinggi profitabilitas yang di peroleh oleh perusahaan, maka ada peluang untuk meningkatkan gaji karyawan.

Adapun jenis-jenis rasio keuangan yang sering digunakan yaitu:

1) Likuiditas

2) Solvabilitas

3) Berputaran Aktiva.

4) Rentabilitas (Profitabilitas)

\section{Likuiditas (Current Ratio)}

Menurut Irham Fahmi, (2012:121) menyebutkan bahwa rasio likuiditas (likuidity ratio) merupakan rasio yang memggambarkan kemampuan perusahaan memenuhi kewajiban (utang) jangka pendek. Artinya apabila perusahaan ditagih, 
maka akan mampu untuk memenuhi utang (membayar) tersebut terutama utang yang sudah jatuh tempo.

\section{Solvabilitas}

Menurut Irham Fahmi,(202:12) menyatakan bahwa solvabilitas merupakan rasio yang menunjukan bagaimana perusahaan mampu untuk mengelola hutangnya dalam rangka memperoleh keuntungan dan juga mampu untuk melunasi kembali hutangnya.

\section{Berputaran Aktiva}

Menurut Irham Fahmi,(2012:132) Menyatakan bahwa perputaran aktiva yang menggambarkan sejauh mana suatu perusahaan mempergunakan sumber daya yang dimilikinya guna menunjang aktivitas perusahaan, dimana penggunaan aktivitas ini dilakukan secara sangat maksimal dengan maksud memperoleh hasil yang maksimal. Rasio ini menunjukan beberapa kali nilai aktiva berputar bila diukur dari volume penjualan.

\section{Laporan Keuangan}

\section{Pengertian laporan keuangan}

Analisis laporan keuangan terdiri dari dua kata yaitu analisis dan laporan keuangan untuk menjelaskan analisis adalah memecahkan atau mengguraikan sesuatu unit menjadi berbagai unit terkecil. Sedangkan laporan keuangan adalah neraca, laba atau rugi, dan arus kas (dana). Kalau dua pengertian ini di gabungkan maka analisa laporan berarti, untuk mengguraikan pos-pos laporan keuangan menjadi unit informasi yang lebih kecil dan melihat hubungan yang bersifat signifikan atau yang mempunyai makna antara satu dengan yang lain baik antara 
kuantitatif maupun non kuantitatif dengan tujuan untuk mengetahui kondisi keuangan lebih dalam yang sangat penting dalam proses menghasilkan keputusan yang tepat (Sofian Syarif Hararap, 2001:192).

\section{Unsur-Unsur Laporan Keuangan}

Menurut Lyn M. Fraser dan Ailen Ormiston (2008:8-10) Menyatakan bahwa unsur-unsur laporan keuangan seperti berikut:

1) Neraca

2) Laporan laba rugi

3) Laporan perubahan modal

4) Laporan catatan atas laporan keuangan

5) Laporan arus kas.

Neraca merupakan laporan yang menunjukkan jumlah aktiva (harta), kewajiban (utang), dan modal perusahaan (ekuitas) perusahaan pada saat tertentu. Artinya dari suatu neraca akan tergambar berapa jumlah harta, kewajiban, dan modal suatu perusahaan.

Laporan laba rugi, menunjukkan kondisi usaha suatu perusahaan dalam suatu periode tertenu. Artinya, laporan laba rugi harus dibuat dalam suatu siklus operasi atau periode tertentu guna mengetahui jumlah perolehan pendapatan penjualan dan biaya yang telah dikeluarkan, sehingga dapat diketahui, perusahaan leader supermarket dalam keadaan laba atau rugi.

\section{Tujuan Dan Sifat Laporan Keuangan.}

Secara umum laporan keuangan bertujuan untuk memberikan informasi keuangan suatu perusahaan, baik pada saat tertentu maupun pada periode tertentu. 
Bahwa laporan keuangan mampu memberi imformasi keuangan kepada pihak dalam dan luar perusahaan yang memiliki kepentingan terhadap perusahaan (Kasmir, (2010:68).

Berikut ini beberapa tujuan pembuatan atau penyusunan laporan keuangan yaitu:

a. Memberi imformasi tentang jenis dan jumlah aktiva (harta) yang dimiliki perusahaan pada saat ini.

b. Memberi imformasi tentang jenis dan jumlah kewajiban dan modal yang dimilki perusahaan pada saat ini.

c. Memberi imformasi tentang jenis dan jumlah pendapatan yang diperoleh pada suatu periode tertentu.

d. Memberi imformasi tentang jumlah biaya dan jenis biaya yang dikeluarkan perusahaan dalam suatu periode tertentu.

e. Memberi imformasi tentang perubahan yang terjadi terhadap aktiva, pasiva, dan modal perusahaan.

f. Memberikan imformasi tentang kinerja manajemen perusahaan dalam suatu periode.

g. Memberi imformasi tentang catatan atas laporan keuangan.

h. Informasi keuangan lainnya.

\section{Teknik Analisis Laporan Keuangan}

Perbandingan adalah teknik analisis laporan keuangan yang dilakukan dengan cara menyajikan laporan keuangan secara horizontal dan membandingkan antara satu dengan yang lain, dengan menunjukkan informasi keuangan atau data 
lainnya dalam nilai mata uang dalam unit, dapat juga dalam persentasi atau perbandingan (Kasmir, (2010:70).

Hal yang perlu di pertimbangkan dalam melakukan analisis perbandingan yaitu:

a. Standar penyusunan laporan keuangan harus sama.

b. Ukuran perusahaan yang akan dibandingkan harus diperhatikan jenis dan bentuknya.

c. Laporan keuangan yang dibandingkan harus sama khususnya untuk laporan laba rugi.

\section{KERANGKA BERPIKIR, KONSEPTUAL DAN HIPOTESIS PENELITIAN}

\section{Kerangka Berpikir Dan Konseptual}

Profitabilitas menurut Van Horne (2005:222) adalah rasio yang menghubungkan laba dari penjualan dan "rasio investasi". Berdasarkan rasio profitabilitas dapat diketahui bagaimana tingkat profitabilitas perusahaan. Setiap perusahaan menginginkan tingkat profitabilitas tinggi. Untuk dapat melangsungkan hidupnya, perusahaan harus berada dalam keadaan yang menguntungkan (profitabile). Apabila perusahaan berada dalam kondisi yang tidak menguntungkan, maka akan sulit bagi perusahaan untuk memperoleh pinjaman dari kreditur maupun investasi dari pihak luar. 


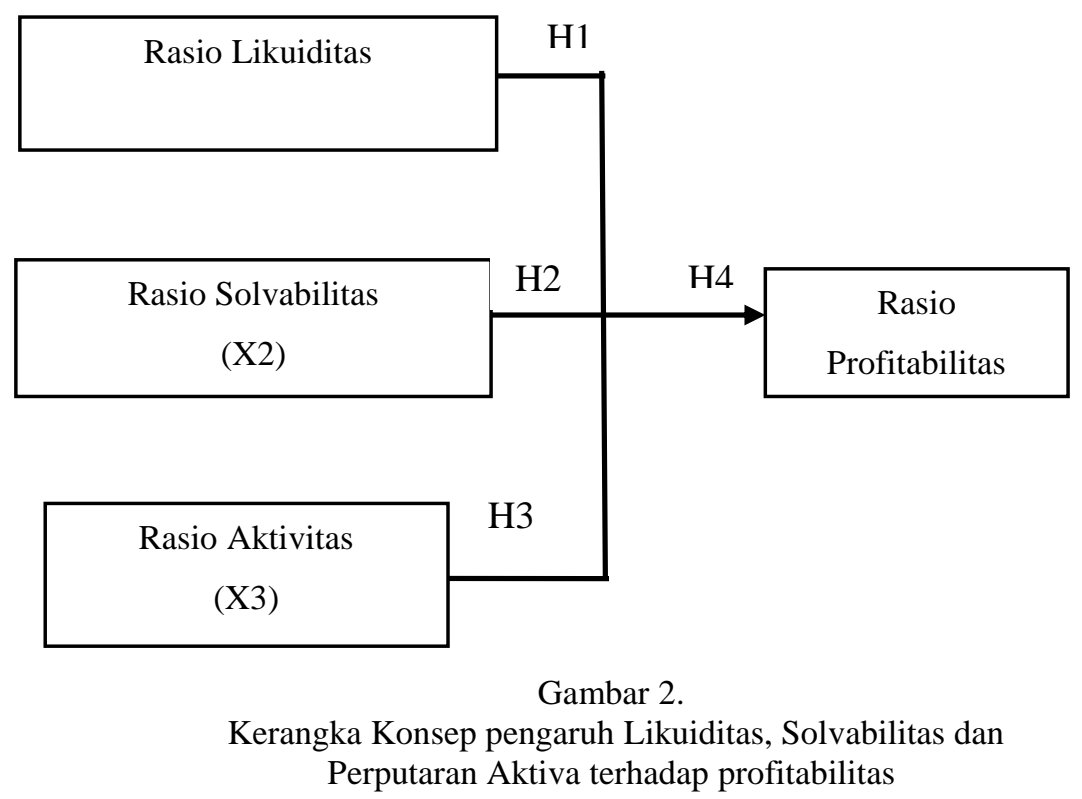

\section{METODE PENELITIAN}

Penelitian ini merupakan penelitian kausalitas, yaitu hubungann sebab akibat yang mengkaji tentang pengaruh efektivitas likuiditas, solvabilitas, perputaran aktiva terhadap profitabilitas pada perusahaan leader Supermarket di Dili Timor-Leste pada periode 2009 - 2013. Tujuan penelitian ini adalah untuk mengetahui hubungan antara dua variabel atau lebih (Sugiyono,2006). Hubungan antara variabel dalam penelitian ini adalah hubungan kausal. Penelitian ini dilakukan di perusahaan leader supermarket di Dili Timoor-Leste pada tahun 2009- 2013.

\section{Variabel Penelitian}

\section{Indentifikasi Variabel}

Variabel penelitian ini meliputi variabel Indepeden dan variabel Depeden. Variabel Indepeden adalah Variabel yang tidak dipengaruhi oleh variabel lainnya 
yaitu likuiditas (X1), solvabilitas (X2), perputaran aktiva (X3) sedangkan variabel Depeden adalah variabel yang dipengaruhi oleh variabel lainnya yaitu Profitabilitas (Y).

\section{Definisi Operasional Variabel}

Definisi operasional adalah suatu definisi yang diberikan kepada suatu variabel dengan cara memberikan arti, menspesifikasi kegiatan ataupun memberikan suatu operasional yang diperlukan, dalam penelitian ini untuk mempermudah dalam menyelesaikan permasalahan, maka perlu mengukur variabel-variabel yang digunakan, dimana variabel dependen (Y) yaitu profitabilitas perusahaan dan variabel indepeden (X) yaitu likuiditas (X1), solvabilitas (X2) perputaran aktiva (X3), sebagai definisi operasional variabelvariabel tersebut adalah:

1) Likuiditas (X1) merupakan rasio yang memggambarkan kemampuan perusahaan memenuhi kewajiban (utang) jangka pendek. Artinya apabila perusahaan ditagih, maka akan mampu untuk memenuhi utang (membayar) tersebut terutama utang yang sudah jatuh tempo, likuiditsd pada perusahaan Leader Supermarket di Dili Timor-Leste pada periode 2009 - 2013 dengan satuan presentase.

Rasio Lancar $=\frac{\text { Aktiva Lancar }}{\text { Hutan Lancar }} \times 100 \%$

2) Solvabilitas merupakan rasio yang menunjukkan bagaimana perusahaan mampu untuk mengelola hutangnya dalam rangka memperoleh keuntungan psda dasar solvabilitasdan juga mampu untuk melunasi kembali hutangnya, 
pada perusahaan leader supermarket periode 2009 - 2013 dengan satuan presentase.

Rasio Hutang atas modal $=\frac{\text { Total Hutang }}{\text { Modal (equity) }} \times 100 \%$

3) Aktivitas merupakan rasio yang menggambarkan sejauh mana suatu perusahaan mempergunakan sumber daya yang dimilikinya guna menunjang aktivitas perusahaan, dimana penggunaan aktivitas ini dilakukan secara sangat maksimal dengan maksud memperoleh hasil yang maksimal pula dengan satuan presentase.

Fixed Asset Turnover $=\frac{\text { penjualan }}{\text { aktiva tetap }} \times 100 \%$

4) Profitabilitas (Y)

Profitabilitas menunjukkan kemampuan supermarket memperoleh laba dari modal yang digunakan tahun 2009 sampai dengan 2013 diukur dengan ROA (Return on Asset) merupakan rasio untuk mengukur kemampuan manajemen perusahaan dalam mengelola moda yang ada untuk mendapatkan net income(Kasmir, 2011) dengan satuan presentase.

ROA $=\frac{\text { LabaBersih }}{\text { TotalAktiva }} \times 100 \%$

\section{Pengumpulan Data}

1) Data kuantitatif yaitu jenis data atau informasi yang dapat dinyatakan dengan angka yang dapat dihitung. Data dalam penelitian ini merupakan data sekunder. Data pengumpulan dan pengelolahannya dilakukan oleh pihak lain 
yang didapat dari manager perusahaan berupa laporan keuangan perusahaan leader supermarket periode 2009-2013.

2) Data kualitatif yaitu data yang tidak berupa angka atau tidak dinyatakan dalam suatu tertentu, namun berupa keterangan atau uraian mengenai perusahaan leader supermarket periode 2009-2013.

\section{Teknik Analisa Data}

Untuk memecahkan permasalahan dalam penelitian sesuai dengan tujuan yang ingin dicapai maka digunakan analisis regresi liner bergada.

\section{Analisis Regresi Liner Berganda}

Dalam penelitian ini digunakan pendekatan SPSS untuk mencari pengaruh antara variabel tersebut dengan model regresi berganda yaitu:

$\mathrm{Y}=0,155$ likuiditas $(\mathrm{x} 1)+0,333$ solvabilitas $(\mathrm{x} 2)+0,803$ perputaran aktiva $(\mathrm{x} 3)$

Keterangan:

$\begin{array}{ll}\text { Y } & \text { : Profitabilitas } \\ \text { X1 } & \text { : Rasio likuiditas } \\ \text { X2 } & \text { : Rasio Solvabilitas } \\ \text { X3 } & \text { : Rasio Aktivitas } \\ \text { Bo } & : \text { Costanta } \\ \text { b1,b2, b3 } & : \text { koefisien regresi } \\ \text { e } & \text { :Standar Eror }\end{array}$




\section{Pengujian Asumsi Klasik}

Menurut Suyana Utama (2007:89) sebelum model regresi digunakan untuk memprediksi beberapa peneliti menganggap perlu mengguji kelayakan model yang dibuat. Untuk itu dilakukan pengujian asumsi klasik yang meliputi Uji Normalitas, Uji Multikulineritas, Uji Autokorelasi.

\section{Uji Normalitas}

Uji normalitas bertujuan untuk menguji apakah dalam residual dari model regresi yang dibuat berdistribusi normal atau tidak. Model regresi yang baik adalah memiliki distribusi residual yang normal atau mendekati normal,pada umumnya regresi dengan residual yang berdistribusi normal diperoleh dari variabel terikat dan variabel bebas keduanya mempunyai distribusi normal atau tidak. Dalam penelitian ini, untuk menguji apakah distribusi data normal, pertama dapat dilakukan dengan melihat normal probability plot yang membandingkan distribusi kumulatif dari data sesungguhnya dengan distribusi kumulatif dari dristribusi normal. Kriteria pengujiannya:

Ho diterima bila $t_{\text {hitung }} \geq t_{\text {tabel }}$

Ho ditolak bila $t_{\text {hitung }}>t_{\text {tabel }}$

\section{Uji Autokorelasi}

Untuk melacak nilai auto korelasi atau pengaruh data dari uji pengamatan sebelumnya dalam model regresi diatas dilakukan uji autokorelasi.

\section{Uji Multikolinearitas}

Uji multikolinearitas berrtujuan untuk menguji apakah pada model regresi ditemukan adanya korelasi antar variabel bebas. Model regresi yang baik 
seharusnya tidak terjadi korelasi diantara variabel bebas. Model regresi yang baik adalah bebas dari gejala multikolinearitas. Jika suatu model regresi yang mengandung gejala multikolinearitas dipaksakan untuk digunakan, maka akan memberikan hasil prediksi yang menyimpang. Untuk mendeteksi ada atau tidaknya korelasi antar sesama variabel bebas dapat dilihat dari nilai tolerance dan nilai variance inflation factor (VIF). Jika nilai tolerance lebih dari 10 persen atau VIF kurang dari 10, maka dikatakan tidak ada multikolinearitas. Adanya gejala multikolinearitas sering di indikasikan oleh $\mathrm{R}^{2}$ yang sangat besar atau Uji $\mathrm{F}$ yang signifikan, tetapi variabel bebas yang signifikan nmelalui uji parsial (t) sedikit atau mungkin tidak ada.

\section{HASIL DAN PEMBAHASAN}

Tabel 2

Statistic Deskriptif Variabel Likuiditas, Solvabilitas, dan Perputaran Aktiva Profitabilitas

\begin{tabular}{|c|c|c|c|c|c|}
\hline & $\mathrm{N}$ & Minimum & Maximum & Mean & Std. Deviation \\
\hline LIKUIDITAS & 5 & 120 & 1431 & 598.43 & 499.259 \\
\hline SOLVABILITAS & 5 & 8 & 314 & 125.16 & 136.806 \\
\hline AKTIVITAS & 5 & 464 & 2234 & 1139.07 & 718.369 \\
\hline $\mathrm{ROA}$ & 5 & 1 & 8 & 4.51 & 2.472 \\
\hline Valid N (listwise) & 5 & & & & \\
\hline
\end{tabular}

\section{Sumber: lampiran2}

Berdasarkan Tabel 2 dapat dijelaskan bahwa variabel profitabilitas (y) yang memiliki rata-rata hitung mean sebesar 4.51 artinya rata-rata tingkat keuntungan (pengembalian) dari modal sendiri yang diinvestasikan perusahaan leader supermarket selama periode 2009-2013 adalah sebesar 4.51 per tahun. Standar deviasi (simpangan baku) variabel profitabilitas adalah 2.472 selama pertahun 
pengamatan, variasi profitabilitas pada perusahaan menyimpang dari rata-ratanya sebesar 2.472,

Profitabilitas terendah (minimum) selama periode pengamatan yaitu pada perusahaan leader supermarket tahun 2009-2013 yaitu 1. Profitabilitas tertinggi (maksimum) selama periode pengamatan yaitu pada perusahaan leader supermarket tahun 2009-2013 yaitu 8

Variabel likuiditas (x1) yang diproyeksikan dengan quick ratio yaitu rasio yang dihitung dari mengurangi persediaan dari aktiva lancar dan dibandingkan dengan hutang lancar, memiliki rata-rata hitung (mean) sebesar 598,43E2 artinya rata-rata kemampuan perusahaan untuk memenuhi kewajiban keuangannya yang akan jatuh tempo selama periode 2009-2013 adalah sebesar 598,43E2 per tahun. Standar deviasi (simpangan baku) variabel likuiditas adalah 499.259 artinya selama tahun pengamatan, variasi tingkat likuiditas pada perusahaan leader supermarket di Dili Timor-Leste menyimpang dari rata-rata sebesar 499.259. Likuiditas terendah (minimum) selama periode pengamatan yaitu pada perusahaan leader supermarket selama periode 2009-2013 yaitu 120 dan likuiditas tertinggi (maksimum) selama perode pengamatan yaitu pada perusahaan leader supermarket di Dili Timor-Leste yaitu 1431 (lampiran I).

Variabel solvabilitas (x2) yang di proyeksikan dengan debt to equity ratio yaitu rasio yang dihitung dari mengurangi persediaan dari total hutang dan dibandingkan modal memiliki rata-rata hitung (mean) sebesar 125.16E2 artinya rata-rata semakin tinggi solvabilitas akan semakin baik, karena ini berarti semakin tinggi efisiensi penggunaan piutangnya dan keuntungan yang diperoleh akan 
semakin besar. Perusahaan leader supermarket selama periode 2009-2013 adalah 125.16E2 pertahun. Standar deviasi (simpangan baku) variabel solvabilitas adalah 136.806 artinya selama tahun pengamatan, variasi solvabilitas pada Perusahaan leader supermarket di Dili Timor-Leste menyimpang dari rata-rata sebesar 136.806. Sedangkan solvabilitas terendah (minimum) selama periode pengamatan yaitu pada perusahaan leader supermarket Dili Timor-Leste yaitu 8\% solvabilitas tertinggi (maksimum) selama perode pengamatan yaitu pada perusahaan leader supermarket Dili Timor-Leste yaitu 314. (Lampiran I).

Variabel perputaran aktiva (x3) yang diproyeksikan dengan Fixed Asset Turnover yaitu membandingkan penjualan dengan aktiva tetap, selama periode 2009-2013 memiliki rata-rata hitung ( mean) sebesar 1139.07E3 artinya semakin tinggi tingkat perputaran aktiva akan memperkecil resiko terhadap kerugian yang disebabkan karena penurunan harga atau karena perubahan selera konsumen, disamping itu akan menghemat ongkos penyimpanan dan pemeliharaan terhadap persediaan tersebut, perusahaan leader supermarket selama periode 2009-2013 yaitu1139.07E3 per tahun. Standar deviasi (simpang baku) variabel perputaran aktiva adalah 718.369 artinya selama pengamatan, variasi rasio perputaran aktiva pada perusahaan leader supermarket Dili Timor-Leste meyimpang dari rataratanya sebesar 718.369 (Lampiran I). 
Tabel 3

Hasil Regresi Liner Berganda Variabel Likuiditas, Solvabilitas dan Perputaran Aktiva pada Perusahaan Leader Supermarket di Dili Timor-Leste dari Tahun $2009-2013$ Coeffcients $^{\mathrm{a}}$

\begin{tabular}{|c|c|c|c|c|c|}
\hline \multirow[b]{2}{*}{ Model } & \multicolumn{2}{|c|}{$\begin{array}{l}\text { Unstandardized } \\
\text { Coefficients }\end{array}$} & \multirow{2}{*}{$\begin{array}{c}\text { Standardized } \\
\text { Coefficients } \\
\text { Beta } \\
\end{array}$} & \multirow[b]{2}{*}{$\mathrm{t}$} & \multirow[b]{2}{*}{ Sig. } \\
\hline & $\mathrm{B}$ & Std. Error & & & \\
\hline 1 (Constant) & 1.651 & .786 & & 2.102 & .283 \\
\hline LIKUIDITAS & .001 & .000 & .155 & 1.595 & .357 \\
\hline $\begin{array}{l}\text { SOLVABILITA } \\
\mathrm{S}\end{array}$ & -.006 & .002 & -.333 & -3.251 & .190 \\
\hline P.AKTIVA & .003 & .000 & .803 & 10.785 & .049 \\
\hline a. Dependent Variable: & & ROA & & & \\
\hline
\end{tabular}

Bedasarkan Tabel 3 dapat persamaan regresi liner berganda seperti berikut: $\mathrm{Y}=0,155$ likuiditas $(\mathrm{x} 1)+-0,333$ solvabilitas $(\mathrm{x} 2)+0,803$ perputaran aktiva $(\mathrm{x} 3)$ Berdasarkan hasil persamaan regresi liner berganda, maka dapat dianalisis sebagai berikut :

1) Koefisien regresi likuiditas sebesar 0,155 berarti bahwa peningkatan terhadap aktiva lancar dikurangi dengan persediaan terhadap kewajiban lancar sebesar satu persen akan meningkat profitabilitas sebesar $0,155 \%$

2) Koefisien regresi dari solvabilitas sebesar -0,333 berarti bahwa peningkatan rasio hutang terhadap modal sebesar satu kali akan meningkatkan profitabilitas sebesar $-0,333 \%$

3) Koefisien regresi perputaran aktiva sebesar 0,803 berati bahwa penjualan terhadap aktiva tetap sebesar satu kali akan meningkatkan profitabilitas sebesar $0,803 \%$. 


\section{Hasil Ujian Asumsi Klasik}

Pengujian terhadap ada tidaknya pelanggaran terhadap asumsi-asumsi klasik yang merupakan dasar dalam model regresi liner berganda. Untuk dapat mengetahui apakah model regresi liner bergada sudah memenuhi sifat Best Linear Umbiased Estimator (BLUE), dilakukan pengujian normalitas, gejala multikolinearitas, dan autokorelasi. Hasil pengujian tersebut adalah sebagai berikut:

\section{Uji Normalitas}

Menurut Ghozali (2005:110), cara untuk mendeteksi apakah residual berdistribusi normal yaitu analisis statistik. Dari hasil pengolaan data diperoleh besarnya nilai kolmogorom-smirnov adalah -0.333 , dan signifikan pada 0.333 . Nilai signifikan ini lebih besar dari 0,05, maka $\mathrm{H} 0$ diterima yang berarti data residual berdistribusi normal. Setelah data berdistribusi normal dapat melanjutkan dengan uji asumsi lainnya.

Tabel 4

Hasil Tests of Normality Variabel, Likuiditas, Solvabilitas, Perputaran aktiva dan Profitabilitas

\begin{tabular}{|c|c|c|c|c|c|c|}
\hline & \multicolumn{3}{|c|}{ Kolmogorov-Smirnov $^{\mathrm{a}}$} & \multicolumn{3}{|c|}{ Shapiro-Wilk } \\
\hline & Statistic & Df & Sig. & Statistic & Df & Sig. \\
\hline Profitabilitas & 0.159 & 5 & 0.159 & 0.992 & 5 & 0.987 \\
\hline Likuiditas & 0.277 & 5 & 0.200 & 0.912 & 5 & 0.230 \\
\hline Solvabilitas & 0.339 & 5 & $0.061^{*}$ & 0.765 & 5 & 0.042 \\
\hline P.Aktiva & 0.201 & 5 & 0.201 & 0.860 & 5 & 0.478 \\
\hline
\end{tabular}

Sumber: lampiran 4

\section{Uji Multikolinearitas}

Pengujian multikolinearitas dilakukan untuk melihat apakah pada model regresi ditemukan adanya korelasi antara variabel bebas. Medel regresi yang baik 
seharusnya tidak terjadi multikolinearitas. Untuk mengetahui terjadi multikolinearitas dapat melihat nilai Variance Inflation Factor (VIF). Menurut Gujarati (2012), pada umumnya. Jika VIF variabel lebih besar dari 5, maka variabel bebas tersebut mempunyai persoalan multikolinearitas dengan variabel bebas lainnya. Hal tersebut terdapat pada Tabel 5 berikut :

Tabel 5

Hasil Uji Multikolinearitas

Variabel piutang, kas, persediaan dan Profitabilitas

\begin{tabular}{lcc}
\hline \multicolumn{1}{c}{ Variabel } & Tolerance & VIF \\
\hline Likuiditas & 0.210 & 4.759 \\
Solvabilitas & 0.135 & 7.401 \\
Aktivitas & 0.393 & 2.542 \\
\hline
\end{tabular}

\section{Depedent variable}

Berdasarkan Tabel 5 diperoleh bahwa semua variabel bebas memiliki nilai tolerance lebih besar dari 0,1 dan nilai VIF jauh di bawah angka 10. Dengan demikian dalam model ini tidak ada masalah multikolinieritas.

\section{1) Hasil Uji Autokorelasi}

Uji autokorelasi bertujuan untuk menguji apakah model regresi linear berganda ada korelasi antara kesalahan penggangu pada periode t-1 (sebelumnya), menurut Ghozali, (2006) model regresi yang baik adalah regresi yang bebas dari autokorelasi. Data yang digunakan untuk uji autokorelasi ini.

Tabel 6

Hasil Uji Autokorelasi Variabel Piutang, Kas,

Persediaan Dan Profitabilitas

Model Summary

\begin{tabular}{llllll}
\hline Model & $\mathrm{R}$ & Square & Adjusted & Std.Error of & $\begin{array}{l}\text { Durbin- } \\
\text { Watson }\end{array}$ \\
& & Square & The Estimate & \\
\hline 0.995 & 0.990 & 0.959 & 0.50348 & 2.545 \\
\hline
\end{tabular}

Sumber: lampiran 5 
Berdasarkan hasil analisis dengan mengunakan SPSS 16 pada output summary terdapat nilai Durbin-Watson sebesar 2.545. sedangkan dari Tabel 5.4 tampak DWsignifikan 0,05 dengan jumlah data $(n)=5$ dan jumlah variabel independen $(\mathrm{k})=3$, menghasilkan nilai DL tidak ada dan DU tidak ada.Karenanilai DW (2,545) jadi berada di luar daerah DL dan DW, maka dapat disimpulkan bahwa model persamaan regresi tersebut ada mengadung masalah autokorelasi.

\section{Hasil Ujian F}

Uji F digunakan untuk menjelaskan variabel bebas likuiditas, solvabilitas dan perputaran aktiva secara serentak atau parsial berpengaruh signifikan terhadap variabel terikat (profitabilitas).

UjiF ditujuhkan untuk mengukur tingkat keberartian hubungan secara keseluruhan koefisien regresi dari variabel bebas terhadap variabel terikat dengan menentukan nilai uji F dengann Tabel ANOVA (Analysis of variance) dan tingkat signifikan.

Tabel 7

Uji F (Simultan)

\begin{tabular}{rlrrrrr}
\multicolumn{7}{c}{ ANOVA $^{\mathrm{b}}$} \\
\hline Model & & Sum of Squares & Df & Mean Square & \multicolumn{1}{c}{ F } & \multicolumn{1}{c}{ Sig. } \\
\hline 1 & Regression & 24.415 & 3 & 8.138 & 293.330 & $.043^{\mathrm{a}}$ \\
& Residual & .028 & 1 & .028 & & \\
& Total & 24.443 & 4 & & &
\end{tabular}

a. Predictors: (Constant), $\mathrm{X} 3, \mathrm{X} 1, \mathrm{X} 2$

b. Dependent Variable: ROA

Pengujian secara simultan menunjukkan bahwa $\mathrm{F}$ rasio untuk model regresi adalah 293,330 dengan tingkat signifikansi $0,043<0,05$ maka tingkat signifikansi model regresi lebih kecil dari tarif nyata. Hasil ini menunjukkan bahwa variabel bebas yaitu likuiditas, solvabilitas dan perputaran aktiva secara 
parsial mempunyai pengaruh yang signifikan terhadap variabel terikat yaitu profitabilitas.

\section{Hasil Uji t}

Uji parsial (uji-t) dilakukan untuk menguji signifikansi pengaruh variabelvariabel bebas (likuiditas, solvabilitas dan perputaran aktiva) secara individual terhadap variabel terikat (profitabilitas) pada perusahaan leader supermarket di Dili Timor-Leste pada tahun 2009 - 2013. Uji-t dalam penelitian ini digunakan untuk melakukan pengujian hipotesis dengan tingkat signifikansi $(\alpha=0,05)$. Uji-t ditunjukkan pada tabel 8 sebagai berikut:

Tabel 8

Uji t (Parsial)

\begin{tabular}{|c|c|c|c|c|c|}
\hline \multirow[b]{2}{*}{ Model } & \multicolumn{2}{|c|}{$\begin{array}{l}\text { Unstandardized } \\
\text { Coefficients }\end{array}$} & \multirow{2}{*}{$\begin{array}{c}\text { Standardized } \\
\text { Coefficients } \\
\text { Beta }\end{array}$} & \multirow[b]{2}{*}{$\mathrm{T}$} & \multirow[b]{2}{*}{ Sig. } \\
\hline & B & Std. Error & & & \\
\hline 1 (Constant) & 1.651 & .786 & & 2.102 & .283 \\
\hline Likuiditas & .001 & .000 & .155 & 1.595 & .357 \\
\hline Solvabilitas & -.006 & .002 & -.333 & -3.251 & .190 \\
\hline Aktivitas & .003 & .000 & .803 & 10.785 & .049 \\
\hline
\end{tabular}

a. Dependent Variabel: Y

Sumber: Output SPSS

Berdasarkan Tabel 6 dapat diketahui pengaruh secara parsial variabelvariabel bebas terhadap variabel terikat sehingga didapat hasil penelitian pada pengujian hipotesis.

\section{Pengujian Hipotesis}

Pengujian hipotesis menunjukkan seberapa jauh pengaruh satu variabel bebas secara individual dalam menerangkan variasi variabel terikat. Pengujian 
hipotesis tentan pengaruh likuiditas, solvabilitas dan perputaran aktiva terhadap profitabilitas dilakukan dengan uji-t dan untuk menunjukkan pengaruh variabel bebas secara bersama-sama terhsdsp variabel terikat melalui uji $\mathrm{F}$ dengan taraf signifikansi 0,05 pada perusahaan leader supermarket di Dili Timor-Leste 2009 2013. Berdasarkan pada Tabel 5.8 maka dapat dilakukan pengujian hipotesis dalam penelitian ini yaitu sebagai berikut :

\section{Uji Hipotesis Pertama}

H1 : Likuiditas berpengaruh positif signifikan terhadap profitabilitas.

Berdasarkan Tabel 5.8 menunjukkan bahwa nilai t sebesar 1,595 signifikansi $0,0375<0,05$. Hasil penelitian ini menerangkan bahwa hipotesis 1 (satu) tidak terbukti berpengaruh positif dan tidak signifikan terhadap profitabilitas pada perusahaan leader supermarket di Dili Timor-Leste.

\section{Uji Hipotesis Kedua}

H2: Solvabilitas berpengaruh negatifsignifikan terhadap profitabilitas. Berdasarkan Tabel 5.6 menunjukkan bahwa nilai t sebesar 3,251 dengan taraf signifikansi $0,190>0,05$. Hasil penelitian ini menyatakan bahwa hipotesis 2 (dua) tidak terbukti berpengaruh negatif namun tidak signifikan terhadap profitabilitas pada perusahaan leader supermarket di Dili Timor-Leste pada periode 2009-2013.

\section{Uji Hipotesis Ketiga}

H3: Perputaran Aktiva berpengaruh positif signifikan terhadap profitabilitas. 
Berdasarkan tabel 5.6 menunjukkan bahwa nilai t sebesar 10,785 dengan taraf signifikansi $0,049<0,05$. Hasil penelitian ini membuktikan kebenaran hipotesis 3 (tiga) atau variabel perputaran aktiva secara parsial berpengaruh positif signifikan terhadap profitabilitas.

\section{Pengaruh Likuiditas Terhadap Profitabilitas}

Hasil pengujian hipotesis diperoleh bahwa likuiditas berpengaruh positif tidak signifikan terhadap profitabilitas pada perusahaan leader supermarket di Dili Timor-Leste periode tahun 2009 - 2013. Pembuktian variabel ini berpengaruh tidak signifikan ditunjukkan dengan derajat signifikansi yang berada di atas 0,05 yaitu sebesar 0,375 sehingga berdasarkan hasil uji tersebut dapat maksudkan bahwa hipotesis 1 (satu) dalam studi ini tidak terbukti kebenarannya, yang menyatakan bahwa rasio likuiditas yang diproyeksikan dengan quick ratio berpengaruh positif signifikan terhadap profitabilitas.

Berdasarkan kondisi pada leader supermarket di Dili Timor-Leste terdapat berbagai kendala dalam suatu perusahaan tersebut terutama pada cuaca maupun suhu yang begitu panas di luar maupun dalam suatu perusahaan itu sendiri, maka terjadinya pembeli yang kurang berkujung atau tidak berminat. Likuiditas ditemukan berpengaruh tidak signifikan terhadap profitabilitas pada perusahaan leader supermarket pada periode 2009-2013. Hal ini menunjukkan bahwa likuiditas tidak mampu meningkatkan profitabilitas pada perusahaan tersebut penyebab likuiditas tidak mampu meningkatkan profitabilitas pada perusahaan leader supermarket karena kas yang dimiliki perusahaan tidak kelola secara optimal setiap periode,sehingga menyebabkan terlalu banyak kas yang ditahan 
dan tidak digunakan sehingga tidak mampu meningkatkan profitabilitasnya. Kondisi initerlihat dari rata-rata hitung (mean) sebesar 598,43E2, artinya dalam setahun $\$ 1$ kas hanya mampu menghasilkan penjualan $\$ 598,43$, ini tergolongkan sangat tinggi perputarannya.

\section{Pengaruh Solvabilitas Terhadap Profitabilitas}

Solvabilitas ditemukan berpengaruh tidak signifikan terhadap profitabilitas pada perusahaan leader supermarket pada periode 2009-2013. Hal ini menunjukkan bahwa solvabilitas semakin tinggi memberikan kredit atau penjualan kepada pelanggan maka menujukkan periode terikat modal, kas akan mampu meningkatkan profitabilitas pada perusahaan leader supermarket karena kas yang dimiliki perusahaan leader supermarket dikelola secara optimal dengan setiap periodeyaitu 2009-2013,sehingga mampu meningkatkan profitabilitasnya. Dengan kondisi ini terlihat dari rata-rata hitung (mean) sebesar 125.16 artinya perusahaan lebih banyak memberikan kredit atau penjualan tunai untuk meningkatkan hasil penjualan kredit pada barang dagangan sehingga profitabilitas juga akan tinggi.

\section{Pengaruh Perputaran AktivaTerhadap Profitabilitas}

Perputaran aktiva ditemukan berpengaruh signifikan terhadap profitabilitas pada perusahaan leader supermarket.Hal ini menunjukkan bahwa perputaran aktiva mampu untuk menjaga stabilitas usahanya sehingga bisa bisa bertahan hidup dan perkembang secara sendiri atau mengukur tingkat efektifitas pemanfaatan sumberdaya perusahaan. aktivitas usaha ini bisa dilihat dari perbandingan penjualan yang masing-masing pos aktiva. Semakin tinggi rasio ini 
semakin efisien perusahaan-perusahaan menggunakan dananya untuk masingmasing aktiva perusahaan tersebut.

\section{Implikasi Penelitian}

Implikasi dari penelitian ini menunjukkan kebijakan keuangan perusahaan leader supermarket Dili Timor-Leste pada periode 2009 - 2913 yaitu variabel likuiditas, solvabilitas dan perputaran aktiva dapat digunakan oleh investor untuk melihat kondisi profitabilitas perusahaan. Investor sebaiknya memperhatikan faktor-faktor keuangan perusahaan yang dapat mempengaruhi profitabilitas yang tinggi, sehingga dapat digunakan untuk mengambil kebijakan dan keputusan yang tepat untuk berinvestasi pada saham di perusahaan leader supermarket Dili Timor-Leste. Hasil penelitian ini juga dapat memberikan bukti empiris bahwa kebijakan keuangan perusahaan berpengaruh signifikan terhadap profitabilitas perusahaan, sehingga keuangan perusahaan perlu dikelola dengan benar oleh manajemen perusahaan agar memberikan keuntungan yang maksimal kepada pemilik perusahaan leader supermarket di Dili Timor-Leste.

\section{SIMPULAN DAN SARAN}

Berdasarkan hasil penelitian dan pembahasan pada bab sebelumnya, maka secara umum dapat disimpulkan: Likuiditas ditemukan berpengaruh positif namun tidak signifikan terhadap profitabilitas pada perusahaan leader supermarkat. Hal ini menunjukkan bahwa likuiditas tidak mampu meningkatkan profitabilitas pada perusahaan tersebut penyebabnya likuiditas tidak mampu meningkatkan profitabilitas pada perusahaan leader supermarket karena kas yang dimiliki 
perusahaan tidak kelola secara optimal setiap periode, sehingga menyebabkan terlalu banyak kas yang ditahan dan tidak digunakan sehingga tidak mampu meningkatkan profitabilitasnya. Kondisi ini terlihat dari rata-rata hitung (mean) sebesar 5.9843. Solvabilitas ditemukan berpengaruh tidak signifikan terhadap profitabilitas pada perusahaan leader supermarket. Hal ini menunjukkan bahwa rasio solvabilitas semakin tinggi memberikan kredit atau penjualan kepada pelanggan maka menujukkan periode terikat modal kerja kas akan mampu meningkatkan profitabilitas pada perusahaan leader supermarket karena kas yang dimiliki perusahaan dengan dikelola yang secara optimal dengan setiap periode sehinggan mampu meningkatkan profitabilitasnya. Dengan kondisi ini terlihat dari rata-rata hitung (mean) solvabilitas sebesar 3.6143. Perputaran aktiva ditemukan berpengaruh positif signifikan terhadap profitabilitas pada perusahaan supermarket. Hal ini menunjukkan bahwa rasio aktivitas mampu meningkatkan profitabilitas pada perusahaan tersebut penyebab perputaran aktiva mampu meningkatkan profitabilitas pada perusahaan leader supermarket karena persediaan penurunan harga yang dimiliki perusahaan dikelola secara optimal setiap periode, sehingga menyebabkan tidak terlalu banyak persediaan yang ditahan dan tidak digunakan sehingga mampu meningkatkan profitabilitasnya.

Berdasarkan pada hasil analisis serta kesimpulan yang telah diuraikan, maka saran yang dapat diberikan pada perusahaan leader supermarket untuk mengingat pengaruh signifikan perputaran aktiva terhadap profitabilitas maka perusahaan leader supermarket harus menjaga rasio aktivitasnya agar tetap baik. 


\section{REFERENSI}

Djarwanto Ps, 2001, Pokok - pokok Analisa Laporan Keuangan, Edisi Pertama, Cetakan Kedelapan, BPFE, Yogyakarta.

Fraser. Lyn M dan Aileen Ormiston, Memahami LaporanKeuangan, PT. Indeks, Indonesia, 2008.

Fahmi Irham, 2011. Analisis Kinerja Keuangan,Penerbit, CV. Alfabeta, Jakarta.

Fahmi, Irham. 2012. Analisis Laporan Keuangan. Bandung: Alfabeta.

Husnan, Sund. 2012 Mangement Keuangan; Teori Penerapan ( Keputusan Jangka Pendek). Edisi keempat, cettakan ketujuh. Yogyakarta: BPFE Uuniversitass Gadjah Mada.

Harahap Sofyan Syafri, 2006, Analisis Kritis Atas Laporan Keuangan, Edisi Pertama, Cetakan Pertama, Raja Grafindo Persada, Jakarta.

Harahap,SofyanSyahfri.2007.Analisa Kritis atas Laporan Keuangan, Edisi

Hasan, Iqbal. 2008. Pokok - pokok Materi Statistik 2 (Statistik inferensif. Edisi kedua, cetakan keempat, Jakarta: Sinar Grafika Offiset.

Gozali, Imam. 2005. Aplikasi Analisis Multivariate Dengan Program SPSS. Semarang: Badan Penerbit Universitas Diponegoro Semarang.

Ghozali, I. 2007. Aplikasi Analisis Multivariate dengan Program SPSS. Cetakan Keempat, Badan Penerbit Universitas Diponegoro: Semarang.

Ikatan Akuntansi Indonesia (IAI). 2004. Pernyataan Standar Akuntansi Keuangan $(P S A K)$, Salemba Empat: Jakarta.

Ikatan Akuntan Indonesia.2007.Standar Akuntansi Keuangan, Jakarta:Salemba Empat.

Inanda, Silvani, 2007. Analisis Laporan Keuangan sebagai Alat Penilaian Kinerja Keuangan, pada PT. Pertamina Ep. Area Rantau Aceh Tamiang, Jurusan Akuntansi Fakultas Ekonomi Universitas Sumatera Utara, Medan.

James C, Van horne\&Jhon M. wachowicz, JR. 2005. Fundamental of Financial Management Prinsip-prinsipManajemen Keuangan (EdisiKeduabelas), : Jakarta.

Kasmir. 2010. Pengantar Manajemen Keuangan, Edisi Pertama. Kencana. Jakarta.

Kasmir. 2012. AnalisaLaporan Keuangan. Cetakan keenam. Jakarta: PT. Raja Grafindo. 
Lazaridis, I. \&Tryfonidis, D. 2006. Relationship between working capital management and profitability of listed companies in the Athens Stock Exchange. Journal of Financial Management and Analysis, Vol. 19, No.1, January-June 2006.

Munawir Harahap, Sofyan Safri. (2006). Analisis Kritis atas Laporan Keuangan, Edisi 1-5. PT. RajaGrafindo Persada. Jakarta

Munawir, 2007. Analisis Laporan Keuangan, Edisi Keempat, Penerbit,Liberty Yogyakarta.

Munawir S. 1995. Analisis Laporan Keuangan Edisi 4, Liberty, Yogyakarta.

Munawir. 2004. AnalisisLaporanKeuangan, Edisi 4, Liberty: Yogyakarta.

Meythi. 2007. Rasio Keuangan yang Paling Baikuntuk Memprediksi Return Saham: Suatu Studi Empirispada Perusahaan Manufaktur Terdaftar di Bursa Efek Jakarta. Jurnal Bisnis dan Akuntansi.

Munawir. S.2010. Analisa Laporan Keuangan. Yogyakarta : Liberty.

Nuugroha, B. 2011. Analisis Pengaruh Modak Kerja Efisiensi Modal Kerja, Likuuiditas, Solvabilitas dan Aktivitas terhadap Profitabilitas (Studi kasus pada PT. Telekomuniikasi Indonesia. Tkb). Jurnal Ilmu Administrasi dan Biisni, UNDIP.

Ormiston, Ailen, dan Lyn M. Fraser, 2008, Memahami Laporan Keuangan, Penerbit Indeks, Jakarta.

Prastowo, Dwi dan Rifka Julianty. 2002. Analisis Laporan Keuangan, AMP YKPN, Yogyakarta

Prastowo, Dwidan Rifka Juliaty, Analisis Laporan Keuangan ,Edisi ke dua, UPP STIM YKPN, Yogyakarta, 2008.

Rahma, Aulia. 2010. Analisis Pengaruh Manajemen Modal Kerja Terhadap Profitabilitas Perusahaan, Studi Pada Perusahaan Manufaktur PMA dan PMDN Yang Terdaftar di BEI periode 2004-2008.

Riyanto, B. 2011. Dasar-dasar Pembelanjaan peruusahaan. Edisi keempat. Cetakan kesebelas.Yogyakarta: BPFE. Universitas Gadjah Mada.

Sartono, Agus. 2010. Manajemen Keuangan Teori dan Aplikasi, Edisi Keempat, Cetakan Ketiga. BPFE. Yogyakarta.

Sartono, A, 2011. Manajemen Keuangan: Teori dan Aplikasi. Edisi keempat cetakann kelima.Yogyakarta:BPFE. Universitas Gadjah Mada. 
Sutrisno.(2009). Manajemen KeuanganTeori, Konsep dan Aplikasi. Yogyakarta: Ekonisia Van Hornes, James C. danJhon M.

Sofyan, Syafri H. (2008) Analisa Kritis Atas Laporan Keuangan. Jakarta: Raja Grafindo Persada.

S. Munawir. (2002).Analisis Laporan Keuangan . Yogyakarta: Liberty.

Sutrisno, 2009. Manajemen Keuangan (Teori, Konsep, dan Aplikasi), Cetakan Ketujuh, Ekonisia, Yogyakarta.

Sugiyono, Statistika Untuk Penelitian, Cetakan Kedua, Bandung, CV Alfabeta, Bandung, 2006.

Sawir, A. 2008. Analisa Kinerja Keuangan dan Perencanaan Keuangan Perusahaan. Cetakan ketiga. Jakarta; PT. Gramedia Pustaka Umum.

Sofyan Syafri Harahap, Menuju Perumusan Teori Akuntansi Islam Pustaka Quantum, 2001.

Santoso, Singgih. 2010. Statistik Multivariat, Jakarta : PT Gramedia

Van horne, James C \& Wachowicz JR, Jhon M. Fundamental of Financial Management/Prinsip-prinsip Manajemen Keuangan. (Edisi Kedua Belas). Salemba Empat, Jakarta.

Wiagustini, Ni luh Putu. 2010. Dasar - Dasar Manajemen Keuangan. Denpasar:Udayana University Press.

Yusuf, Muhammad dan Soraya.2004. "Faktor-Faktor yang Mempengaruhi Praktik Perataan Laba Pada Perusahaan Asing dan Non Asing di Indonesia”.JAAI. Vol.8, No. 1, Juni. 